Proceeding of ICECRS, 1 (2016) 635-646

ISSN. 2548-6160

International Seminar on Generating Knowledge Through Research, UUM-UMSIDA, 25-27 October 2016, Universiti Utara Malaysia, Malaysia.

Available online: http://ojs.umsida.ac.id/index.php/icecrs

Article DOI: http://dx.doi.org/10.21070/picecrs.v1i1.535

\title{
TAHAP IKLIM SEKOLAH, TAHAP KOMITMEN GURU SERTA HUBUNGAN DI ANTARA IKLIM SEKOLAH DENGAN KOMITMEN GURU SEKOLAH-SEKOLAH MENENGAH DAERAH MACHANG, KELANTAN.
}

\author{
Suhaili binti Mohd Yusoff \\ Tembam77@yahoo.com \\ Khaliza binti Saidin \\ Pusat Pengajian Pendidikan dan Bahasa Moden, Universiti Utara Malaysia
}

\begin{abstract}
ABSTRAK: Kertas kerja ini adalah bertujuan bagi mengenalpasti tahap iklim sekolah, tahap komitmen guru, tahap komitmen guru berdasarkan pengalaman mengajar dan jantina guru serta hubungan di antara iklim sekolah dengan komitmen guru bagi guru sekolah-sekolah menengah Daerah Machang, Kelantan. Disamping itu, kertas kerja ini juga mengkaji dimensi iklim sekolah yang sangat kuat mempengaruhi tahap komitmen guru. Dimensi iklim sekolah adalah merangkumi dimensi bekerjasama, dimensi membuat keputusan, dimensi inovasi pengajaran, dimensi hubungan dengan murid dan dimensi sumber-sumber sekolah. Seramai 248 orang guru sekolah menengah terlibat sebagai sampel kajian berdasarkan jumlah populasi iaitu seramai 678 orang guru. Sebanyak 7 buah sekolah diambil sebagai sampel kajian dan sampel kajian dipilih secara rawak. Data dianalisis dengan menggunakan Statistical Package for Social Sciences (SPSS) versi 20.0 untuk analisis deskriptif. Kajian ini mendapati bahawa terdapat signifikan dan positif serta menunjukkan hubungan pada tahap yang sederhana di antara iklim sekolah dengan komitmen guru $(\mathrm{r}=0.506, \mathrm{p}<0.01)$. Korelasi Pearson digunakan sebagai statistik inferensi pembolehubah bebas iaitu iklim sekolah dengan pembolehubah bersandar iaitu komitmen guru. Secara keseluruhannya, kajian ini menunjukkan bahawa terdapat beberapa dimensi iklim sekolah yang mempengaruhi komitmen guru seperti kerjasama $(\beta=0.242, t=03.873)$, membuat keputusan $(\beta=0.331, \mathrm{t}=5.036)$ and inovasi pengajaran $(\beta=0.300, t=4.295)$. Walau bagaimanapun, dimensi membuat keputusan adalah dimensi yang paling berpengaruh terhadap komitmen guru. Oleh itu, kajian ini mencadangkan bahawa sekiranya pihak pengurusan sekolah berhajat untuk meningkatkan komitmen guru, penglibatan guru dalam proses membuat keputusan perlulah di pertingkatkan.
\end{abstract}

KATA KUNCI: Iklim sekolah, Komitmen guru dan sekolah menengah.

\section{PENGENALAN}

Pendidikan merupakan wadah utama bagi menjayakan pembangunan negara dan menjadi alat penting dalam melahirkan sumber tenaga melalui agenda melahirkan modal insan minda kelas pertama (Kementerian Pelajaran Malaysia, 2007). Lantaran itu Kementerian Pendidikan Malaysia telah mengorak langkah proaktif ke arah memartabatkan kualiti pendidikan di Malaysia hingga bertaraf dunia, di samping menjadikannya sebagai pusat kecemerlangan tamadun ilmu (Alimuddin Mohd Dom, 2008). Guru yang komited dalam mendidik anak muridnya merupakan pencetus kepada hasrat tersebut. Maka itu, hasrat memartabatkan kualiti pendidikan Malaysia akan tercapai.

Institusi pendidikan seharusnya mempunyai persekitaran yang positif dan kondusif. Ini kerana kejayaan sesebuah organisasi atau institusi terletak di tangan pekerja yang menganggotai organisasi tersebut. Ianyabermaksud bahawa merekalah yang bertanggungjawab untuk mencapai matlamat dan wawasan 
organisasi berkenaan (Maisura Mohd Yunus, 2007). Satu cara yang menunjukkan komitmen di kalangan guru adalah dengan cara mereka lebih suka melibatkan diri pada apa yang diceburi (Nias, 1981; Tyree, 1996). Selain daripada itu, komitmen guru telah di kenal pasti sebagai salah satu faktor kritikal untuk kejayaan masa hadapan dalam bidang pendidikan (Huberman, M., 1993).Maka, di dalam Anjakan ke empat Pelan Pembangunan Pendidikan Malaysia 2013-2015 (PPPM) ianya memberi penekanan kepada keberhasilan guru yang berkualiti dan komited yang dapat menyumbangkan ilmu dan tenaga ke tahap maksimum demi melonjakkan imej negara dalam ekonomi dunia melalui transformasi pendidikan.

Iklim organisasi memberi impak yang besar ke atas kejayaan dan kegagalan sesebuah organisasi. Pengurus merupakansumber manusia yang paling penting dalam meneraju organisasi dan mereka juga berperanan dalam mewujudkan iklim yang harmoni kepada pekerja yang merupakan pelanggan dalaman bagi sesebuah organisasi untuk mencapai matlamat individu dan organisasi.Halpin dan Croft (1963) merupakan perintis dalam kajian iklim sekolah mengatakan bahawa iklim sekolah menggambarkan personaliti seseorang guru itu sendiri dan bagaimana guru tersebut berusaha untuk mencapai tahap organisasi iklim sekolah berkenaan. Seterusnya, Howard (1974) pula mendefinisikan iklim sekolah sebagai keadaan sosial dan budaya sekolah itu yang mempengaruhi tingkah laku orang di dalamnya.

Bagi pendapat Steers (1997) terdapat beberapa faktor peribadi yang berhubung dengan komitmen pekerja terhadap organisasi seperti umur dan jantina, struktur organisasi, taraf pendidikan, peranan tugas dan kebajikan kepada pekerja. Faktor-faktor ini menunjukkan kesan terhadap komitmen. Menurut beliau, pekerja wanita mempunyai tahap komitmen yang lebih tinggi berbanding pekerja lelaki, tahap kematangan pekerja iaitu pekerja yang lebih matang mempunyai tahap komitmen yang lebih tinggi berbanding dengan pekerja yang lebih muda.

Selain daripada itu, beliau menyatakan juga bahawa mereka yang mempunyai taraf pendidikan yang lebih tinggi mempunyai tahap komitmen yang lebih rendah berbanding pekerja yang mempunyai tahap pendidikan yang lebih rendah. Menurut Steers juga, tahap komitmen pekerja juga akan tinggi sekiranya organisasi memberi kebebasan kuasa dalam membuat keputusan sendiriserta diberi tanggungjawab dan kepercayaan terhadap tugas yang diberikan. Dari aspek peranan tugas, pekerja akan lebih komited sekiranya tugas yang diberikan oleh organisasi itu lebih jelas dan akan komited sekiranya lebih berkemahiran dan pakar dalam sesuatu bidang kerja. Pihak pekerja akan menunjukkan tahap komitmen yang tinggi jika pihak organisasi mengambil berat akan kebajikan mereka.

\section{PERNYATAAN MASALAH}

Komitmen guru adalah sangat penting kepada organisasi sekolah untuk mencapai matlamat sekolah kerana tugas guru bukan sekadar mengajar dan memberikan ilmu kepada pelajar, malah menentukan maju atau mundur sesebuah negara (Sabaruddin Yusof, 1993). Justeru itu, perlu ada kajian mahupun penambahbaikan yang berterusan terhadap komitmen guru khasnya guru Malaysia walaupun isu komitmen guru di Malaysia bukan satu isu yang baru diberi perhatian. Seterusnya membuat tindakan yang proaktif supaya tahap komitmen guru dapat dipertingkatkan lagi mengikut kehendak dan situasi semasa. Sebagai contohnya, seperti apa yang diperkatakan oleh Prof. Madya Dr. Saodah Abd. Rahman dalam Utusan Malaysia bertarikh 5 Ogos 2016 iaitu bagi pandangan beliau keperluan guru pada masa sekarang adalah sebagai seorang pengasuh, pendidik yang mudarris, mualim, muaddib, murabbi dan mursyid diperlukan dalam dunia pendidikan sekarang. Selain daripada itu, kajian terdahulu juga banyak mengkaji isu komitmen guru dan hubungannya dengan pembolehubah bebas seperti apa yang terdapat dalam salah satu dimensi iklim sekolah . Namun, kajian komitmen guru yang dikaitkan dengan iklim sekolah tidak banyak dibuat kerana pengkaji terdahulu lebihmenumpukan beberapa dimensi dalam iklim sekolah untuk dibuat penyelidikan dan bukan keseluruhan dimensi dalam konstruk tersebut. Sebagai contohnya, beberapa kajian melaporkan bahawa terdapat kaitan antara komitmen guru terhadap organisasi sekolah dengan penglibatan mereka dalam membuat sesuatu keputusan di sekolah (Firestone, W. A., \& Pennell, J. R., 1993; Somech \& Bolger, 2004). Laporan dalam kajian-kajian ini menunjukkan bahawa penglibatan guru dalam membuat keputusan pengurusan adalah satu strategi yang perlu digunakan oleh pihak pengurusan di 15 buah sekolah untuk 
meningkatkan komitmen guru terhadap sekolah dan seterusnya mencapai matlamat kecemerlangan sekolah. Oleh itu, ia menunjukkan bahawa dimensi membuat keputusan dijadikan pemboleh ubah bebas dalam kajian tersebut dan ia merupakan hanya salah satu daripada dimensi iklim sekolah yang dibangunkan oleh fisher \& Fraser (1990).Sedangkan di dalam kajian ini, semua dimensi iklim sekolah dijadikan sebagai pembolehubah bebas untuk melihat perhubungannya dengan komitmen guru.

Selain daripada itu, isu komitmen ini perlu dikaji semula kerana melalui dapatan lain ianya masih menunjukkan bahawa komitmen guru di Malaysia masih di tahap sederhana (Mohd Ramzan Awang, 2014). Menurut Ong Chong Sooi (1995), komitmen guru pada pengajaran adalah lebih rendah jika dibandingkan dengan komitmen pada profesion. Sering kita dengar bahawa terdapat juga dikalangan guru yang memohon untuk berpencen lebih awal, menjalankan pekerjaan sampingan yang memberi kesan kepada mutu pengajaran, kerap memohon untuk bercuti dan sebagainya. Oleh itu, satu persoalan yang masih berlegar iaitu adakah komitmen guru Malaysia masih rendah? Maklumat yang diambil dari Unit Perkhidmatan Guru (2004), mendapati terdapat ramai guru yang memohon untuk bersara awal, tetapi KPM meminta mereka untuk menimbang semula keputusan atas sebab situasi kekangan dalam pendidikan. Sepanjang tahun 2003, seramai 529 orang guru telahmeletak jawatan secara opsyenal manakala seramai 412 orang guru telah meletak jawatan atas alasan peribadi.

Dr. Sapora Sipon dalam Utusan Malaysia bertarikh 27 Julai 2007 menyatakan bahawa profesion perguruan dilihat sebagai satu profesion yang sering meletihkan dan banyak mengundang tekanan dan memberi kesan yang negatif kepada ahli-ahlinya. Guru yang terlalu terbeban bidang tugasnya dan akibatnya merasa tertekan akan memberi kesan negatif kepada mutu pendidikan negara. Dr. Sapora Sipon (2007)juga menambah bahawa isu-isu pendidikan seperti masalah disiplin pelajar yang berleluasa, bebanan tugasan, masalah kekurangan guru, kekurangan bilik darjah, konflik peranan, kekaburan peranan dan rangkaian masalah lain yang tidak dapat diselesaikan dengan memuaskan boleh menggugat kesejahteraan guru.

Sekiranya isu guru terlalu terbeban tidak diatasi segera, ia boleh menyebabkan guru merasa tertekan dan memohon untuk meletak jawatan atau memohon untuk bersara. Sehubungan dengan itu, timbul satu persoalan, adakah hal-hal demikian mempunyai kaitan dengan isu komitmen guru dan adakah hal-hal demikian mempunyai perkaitan di antara komitmen guru dengan iklim sekolah?. Adakah guru-guru terbeban ini disebabkan oleh iklim sekolah yang masih tidak kondusif?.

Abdul Manaf Musa(1998) menyatakan bahawa terdapat hubungan yang positif dan signifikan diantara iklim organisasi (aspek sosial sekolah, fizikal sekolah, dan aspek pentadbiran sekolah) dengan komitmen guruguru terhadap organisasi. Kajian ini dijalankan oleh Abdul ManafMusa kepada sekolah-sekolah rendah Pulau Pinang. Namun begitu terdapat juga hubungan yang tidak signifikan diantara hubungan iklim sekolah dengan komitmen dan dapatan ini yang tidak konsisten kerana disebabkan oleh terdapat terlalu banyak dimensi yang terdapat dalam iklim sekolah (Sainul Hermawan, 2008). Sementara itu, terdapat juga dapatan yang tidak konsisten jika dikaitkan dengan iklim sekolah kerana konstruk yang pelbagai, serta penggunaan dimensi yang juga pelbagai serta jumlah persampelan yang tidak sama memungkinkan dapatan kajian berbeza. Oleh itu, kajian perlu dijalankan kerana didapati isu komitmen guru di Malaysia masih belum menunjukkan peningkatan komitmen yang baik kerana dapatan pada 1995 dan dapatan pada 2014 masih menunjukkan tahap komitmen yang masih sama.

Maka itu, berdasarkan kepada dapatan kajian ini, di harap ianya dapat menjadi titik tolak kepada perubahan yang lebih drastik dalam diri setiap individu yang bergelar guru supaya menjadi lebih komited terhadap bidang tugas sebagai pendidik. Bagi pentadbir pula, mereka yang dikatakan tunjang utama kepada jatuh bangunnya sesebuah sekolah, perlulah menyediakan dan memastikan iklim sekolah lebih berkesan dan memberi suasana yang kondusif di sekolah.

\section{OBJEKTIF KAJIAN}


Kertas kajian ini dibuat bagi mengenalpasti tahap iklim sekolah dan tahap komitmen guru berdasarkan demografi iaitu faktor jantina dan pengalaman mengajar guru. Kertas kajian ini juga adalah bertujuan mengenalpasti hubungan di antara iklim sekolah dengan komitmen guru serta mengenalpasti dimensi iklim sekolah yang paling kuat mempengaruhi komitmen guru.

\section{PERSOALAN KAJIAN}

Dalam kajian ini terdapat beberapa persoalan yang ditimbulkan. Ia merangkumi:

1. Apakah tahap komitmen guru-guru sekolah menengah Daerah Machang?

2. Apakah tahap iklim sekolah bagi sekolah-sekolah menengah Daerah Machang?

3. Adakah terdapat perbezaan komitmen guru-guru sekolah menengah Daerah

4. Machang berdasarkan faktor jantina?

5. Adakah terdapat perbezaan komitmen guru-guru sekolah menengah Daerah Machang berdasarkan pengalaman mengajar?

6. Adakah terdapat hubungan yang signifikan antara iklim sekolah dengan komitmen guru sekolahsekolah menengah Daerah Machang dan apakah dimensi iklim sekolah yang memberi pengaruh tertinggi terhadap komitmen guru?.

\section{METODOLOGI}

Kertas kajian ini berbentuk kajian kuantitatif dan menggunakan tinjauan rentas dan menggunakan soalan ' closed- ended' dimana responden diberikan pilihan yang terhad untuk mendapatkan jawapan kepada soal selidik yang diberikan. Untuk kertas kajian ini, populasi kajian merangkumi semua guru sekolah menengah harian Daerah Machang seramai 678 orang dan bilangan sampel yang diambil ialah seramai 248 orang (Krejcie, Morgan, 1970). Populasi guru-guru sekolah menengah ini terdiri daripada beberapa buah sekolah iaitu SMK Sultan Abdul Samad, SMK Machang, SMK Hamzah, SMK Hamzah 2, SMK Seri Intan, SMK Temangan, dan SMK Pangkal Meleret. Kertas kajian ini menggunakan instrumen yang jelas kesahan dan kebolehpercayaan pada Alpha Cronbach 7.0 ke atas berdasarkan kepada ujian yang telah dijalankan oleh pembina instrumen tersebut. Kajian ini telah di buat adaptasi dari aspek penggunaan skala Likert di mana kajian ini telah menggunakan 7 skala Likert berbanding 5 skala Likert asal yang dibina oleh Johnson et al. (2007). Ini kerana ia adalah lebih baik kerana dapat memberikan pilihan jawapan yang lebih tepat kepada responden. (Sauro, J., 2010).

Instrumen komitmen guru telah dibuat adaptasi oleh Lei Mee Thien, Nordin Abdul Razak, dan T. Ramayah Walau bagaimanapun, instrumen ini asalnya mempunyai 17 item dan apabila telah dibuat keesahan dengan analisa menggunakan analisis faktor ( EFA) dan Confirmatory Factor Analysis (CFA) dengan SPSS 19.0 dan AMOS 19, hanya 13 item sahaja yang dicadangkan untuk digunakan. Instrumen ini mengandungi 4 dimensi iaitu komitmen pada sekolah, komitmen pada murid, komitmen pada pengajaran dan komitmen pada profesion.

Jadual 1

Taburan Item Instrumen Dimensi Komitmen Guru

\begin{tabular}{lcl} 
Dimensi Komitmen Guru & Nombor Item & Bilangan Item \\
\hline Komitmen Pada Sekolah & 22,23 dan 24 & 3 \\
Komitmen Pada Murid & 25,26 dan 27 & 3 \\
Komitmen Pada Pengajaran & 29,30 dan 31 & 3 \\
Komitmen Pada Profesion & $28,32,33$ dan 34 & 4
\end{tabular}

638 
Bagi mengukur pemboleh ubah bebas iaitu iklim sekolah, School level environment Questionnaire (SLEQ) yang dibina oleh Johnson et al. (2007) telah digunakan. Pengkaji telah membuat tafsiran ke dalam Bahasa Melayu disebabkan oleh instrumen asal SLEQ adalah berbahasa Inggeris .Instrumen ini mengandungi 21 item dengan lima dimensi iaitu (1) kerjasama, (2) inovasi pengajaran, (3) membuat keputusan, (4) hubungan dengan murid, dan (5) sumber sekolah. Instrumen ini juga menggunakan skala Jenis Likert 7 mata iaitu di antara 1 untuk sangat tidak setuju dan 7 untuk sangat setuju.

Jadual 2

Taburan Item Instrumen Dimensi Iklim Sekolah

\begin{tabular}{lcl}
\hline Dimensi Iklim Sekolah & Nombor Item & Bilangan Item \\
\hline Kerjasama & $1,2,3,4,5$ dan 6 & 6 \\
Hubungan Dengan Murid & $7,8,9$ dan 10 & 4 \\
Sumber-sumber Sekolah & $11,12,13$ dan 14 & 4 \\
Membuat Keputusan & 15,16 dan 17 & 3 \\
Inovasi Pengajaran & $18,19,20$ dan 21 & 4 \\
$\quad$ & & 21 \\
\hline \multicolumn{1}{c}{ Jumlah Item } & & \\
\hline
\end{tabular}

Penilaian dalam menginterpretasikan data min dibahagikan kepada enam julat skor min. Tafsiran skala min ini adalah adaptasi daripada Chua Y. P. (2009).

Jadual 3

Tafsiran Skala Min

\begin{tabular}{ll}
\hline Julat Skor Min & Interpretasi \\
\hline$>6.00$ & Sangat tinggi \\
$5.00-5.99$ & Tinggi \\
$4.00-4.99$ & Agak tinggi \\
$3.00-3.99$ & Agak rendah \\
$2.00-2.99$ & Rendah \\
$1.00-1.99$ & Sangat rendah \\
\hline
\end{tabular}

Sumber: Chua Y. P. (2009)

Bagi mentafsir hubungan diantara dua pembolehubah pula, interpretasi saiz korelasi yang dicadangkan oleh Hair, Money, Samouel\&Page(2007) digunakan dalam kajian ini. Penerangan bagi menentukan saiz korelasi adalah seperti yang ditunjukkan dalam Jadual.

Jadual 4

Nilai Pekali Korelasi

\begin{tabular}{ll}
\hline Nilai r & \multicolumn{1}{c}{ Tafsiran Pekali } \\
\hline $.91-1.00$ & Korelasi Sangat Tinggi \\
$.71-.90$ & Korelasi Tinggi \\
$.41-.70$ & Korelasi Sederhana \\
$.21-.40$ & Korelasi Rendah \\
$.01-.20$ & Korelasi Sangat Rendah
\end{tabular}


$.00 \quad$ Tiada Korelasi

Sumber: Hair, J. F., Money, A. H., Samouel, P.,\& Page, M. (2007)

Kajian rintis juga telah dijalankan kepada 30 orang responden yang merupakan guru-guru sekolah menengah di Daerah Machang apabila surat kelulusan diterima darapada JPN Kelantan .

\section{DAPATAN}

Sebagai pendahuluan, maklumat berkenaan jantina guru, pengalaman mengajar disertakan berdasarkan Jadual 5 dan Jadual 6. Analisis deskriptif digunakan untuk menerangkan maklumat berkaitan jantina guru dan pengalaman mengajar guru. Berdasarkan Jadual 5, Bilangan responden yang terdiri daripada guru lelaki ialah $34.7 \%$ manakala responden yang terdiri daripada guru perempuan ialah 65.3\%. Jadual 6 pula adalah berkaitan pengalaman mengajar guru. Analisis deskriptif ini menunjukkan bahawa hanya 9 orang guru sahaja yang mempunyai pengalaman mengajar kurang daripada 10 tahun, 107 orang guru yang mempunyai pengalaman mengajar diantara 10-20 tahun, seramai 109 orang guru pula didapati mempunyai pengalaman mengajar selama diantara 21-30 tahun dan seramai 23 orang guru yang mempunyai pengalaman mengajar melebihi 30 tahun.

Jadual 5

Bilangan Responden Berdasarkan Jantina

\begin{tabular}{lll}
\hline Jantina & Bilangan & Peratus \\
\hline Lelaki & 86 & 34.7 \\
Perempuan & 162 & 65.3 \\
\hline Jumlah & 248 & 100.0 \\
\hline
\end{tabular}

Jadual 6

Bilangan Responden Berdasarkan Pengalaman Mengajar

\begin{tabular}{lll}
\hline Pengalaman Mengajar & Bilangan & peratus \\
\hline$<10$ tahun & 9 & 3.6 \\
$10-20$ tahun & 107 & 43.1 \\
$21-30$ tahun & 109 & 44.0 \\
$>30$ tahun & 23 & 9.3 \\
\hline Jumlah & 248 & 100.0 \\
\hline
\end{tabular}

Untuk menjawab beberapa persoalan kajian ini, dapatan kajian menunjukkan bahawa:

Tahap Iklim Sekolah dan Komitmen Guru-guru Sekolah Menengah Daerah Machang

Jadual 7

Tahap Iklim Sekolah dan Komitmen Guru-Guru Sekolah Menengah Daerah Machang

\begin{tabular}{lll}
\hline Pembolehubah & Min & SP \\
\hline & & \\
Komitmen Guru & 4.67 & .65 \\
Iklim Sekolah & 5.15 & .52 \\
\hline
\end{tabular}

Merujuk kepada Jadual 7, ia menunjukkan min tahap komitmen guru dan juga tahap iklim sekolah. Nilai tahap adalah berdasarkan kepada tafsiran skor min yang dibahagikan kepada 6 tahapiaitu skor min sangat rendah 
iaitu <1.99 skor min rendah iaitu diantara 2.00-2.99, dan skor min agak rendah iaitu diantara 3.00-3.99, min tahap agak tinggi iaitu pada nilai min diantara 4.00-4.99, min pada tahap tinggi iaitu pada 5.00-5.99 dan nilai min bagi tahap sangat tinggi iaitu melebihi 6.00. Oleh itu, dapat disimpulkan di sini bahawa tahap bagi komitmen guru bagi sekolah-sekolah menengah Daerah Machang adalah sederhana tinggi $(\mathrm{M}=4.67, \mathrm{SP}=0.65)$ dan tahap iklim sekolah juga pula berada pada tahap tinggi $(M=5.15, S P=0.52)$. Ini menunjukkan persepsi guru-guru sekolah menengah Daerah Machang terhadap iklim sekolah dan juga komitmen.

Perbezaan Komitmen Guru-Guru Sekolah Menengah Daerah Machang Berdasarkan Faktor Jantina

Jadual 8

Keputusan Ujian-t Sampel Bebas Komitmen Guru Sekolah Menengah Daerah Machang Berdasarkan Jantina

\begin{tabular}{lllllll}
\hline Jantina & $\mathrm{N}$ & $\mathrm{Min}$ & $\mathrm{SP}$ & $\mathrm{dk}$ & $\mathrm{t}$ & $\mathrm{P}$ \\
\hline Lelaki & & & & & & \\
Perempuan & 86 & 5.01 & .544 & 159.961 & -2.975 & 0.003 \\
\hline
\end{tabular}

${ }^{*} \mathrm{p}<.05$

Jadual 8 menunjukkan keputusan ujian-t sampel bebas berdasarkan komitmen guru mengikut jantina. Setelah ujian tersebut dijalankan, ujian Levenedidapati menunjukkan nilai yang signifikan $(p<.05)=.029$. Ini menunjukkan bahawa varians di antara guru lelaki dan guru perempuan adalah tidak sama dan tidak memenuhi kehomogenan varians antara guru lelaki dan guru perempuan dalam komitmen. Selain daripada itu, melalui bahagian $t$-test for equality of means, di dapati nilai $\mathrm{t}(159.961)=-2.975, \mathrm{p}<0.05$. Oleh sebab nilai sig. ( 2 tailed) bersamaan 0.003 iaitu $p<0.05$, maka ia memberi maksud bahawa terdapat perbezaan yang signifikan bagi pembolehubah bersandar komitmen guru berdasarkan jantina. Kesimpulannya, min komitmen guru lelaki dan perempuan di Daerah Machang adalah berbeza iaitu komitmen guru perempuan (5.220) dan guru lelaki (5.011).

Perbezaan Komitmen Guru-Guru Sekolah Menengah Daerah Machang Berdasarkan Faktor Pengalaman Mengajar

Jadual 9

Keputusan Ujian Anova Satu Hala Komitmen Guru Sekolah Menengah Daerah Machang Berdasarkan Pengalaman Mengajar

\begin{tabular}{llll}
\hline PengalamanMengajar & $\mathrm{N}$ & Min & SP \\
\hline$<10$ tahun & 9 & 5.264 & .402 \\
$10-20$ tahun & 107 & 5.220 & .482 \\
$21-30$ tahun & 109 & 5.024 & .532 \\
$>31$ & 23 & 5.354 & .573 \\
\hline Jumlah & 248 & 5.148 & .521 \\
\hline
\end{tabular}

Jadual 10

Ujian kehomogenan Varians

\begin{tabular}{llll}
\hline Statistik Levene & $\mathrm{dk} 1$ & $\mathrm{dk} 2$ & $\mathrm{p}$. \\
\hline 1.160 & 3 & 244 & .330 \\
\hline
\end{tabular}




\begin{tabular}{llllll}
\hline sumber & Sum of Squares & $\mathrm{dk}$ & Mean Square & $\mathrm{F}$ & $\mathrm{p}$ \\
\hline Antara kumpulan & 3.308 & 3 & 1.103 & 4.222 & .006 \\
Dalam kumpulan & 63.716 & 244 & .261 & & \\
\hline Jumlah & 67.024 & 247 & & & \\
\hline$p<.05$ & & & &
\end{tabular}

Jadual 9 dan 10 menunjukkan keputusan ujian Anova Satu Hala komitmen guru berdasarkan pengalaman mengajar. Setelah analisis statistik dikeluarkan, keputusan ujian Levene adalah tidak signifikan ( $p>05)$. Keputusan ini menunjukkan wujudnya kehomogenan varians antara komitmen guru dengan pengalaman mengajar $p=.327$. Ujian Anova Sehala adalah signifikan $(p<.05)$. Keputusan menunjukkan nilai adalah kecil $(p=.006)$ berbanding dengan nilai alpha $(\alpha=.05)$ dan statistik $F(4.222)$.

Hubungan di antara Iklim Sekolah Dengan Komitmen Guru-Guru Sekolah Menengah Daerah Machang Serta Pengaruh Tertinggi Dimensi Iklim Sekolah Terhadap Komitmen Guru.

Jadual 11

Statistik Deskriptif

\begin{tabular}{lll}
\hline Pemboleh ubah & Min & SP \\
\hline Komitmen Guru & 4.67 & .65 \\
Iklim Sekolah & 5.15 & .52 \\
\hline
\end{tabular}

Jadual 12

Hubungan Diantara Iklim Sekolah dengan Komitmen Guru-guru Sekolah Menengah Daerah Machang

\begin{tabular}{llll}
\hline & & Komitmen & Iklim \\
\hline \multirow{3}{*}{ Komitmen } & Korelasi Pearson & 1 & $.506^{* *}$ \\
& Sig. (2-tailed) & & .000 \\
$\mathrm{~N}$ & 248 & 248 \\
Kklim & Korelasi Pearson & $.506^{* *}$ & 1 \\
& Sig. (2-tailed) & .000 & \\
$\mathrm{~N}$ & 248 & 248 \\
\hline
\end{tabular}

** Korelasi adalah signifikan pada aras keertian 0.01(2-tailed)

Berdasarkan Jadual 12 iaitu dapatan Analisa Korelasi di atas, nilai $\mathrm{p}<.01$,iaitu keputusan ini menunjukkan bahawa komitmen guru secara signifikan mempunyai hubungan yang positif dengan iklim sekolah dan hubungan tersebut adalah sederhana $(r=.506, p<0.01)$. Ini menunjukkan bahawa sekiranya iklim sekolah berada dalam keadaan yang positif, tahap komitmen guru juga akan bertambah. Seterusnya, untuk objektif kajian kelima juga, iaitu melihat dimensi tertinggi bagi iklim sekolah yang mungkin mempengaruhi komitmen guru berdasarkan 5 dimensi yang digunakan dalam kerangka kajian ini iaitu hubungan dengan murid, bekerjasama, inovasi pengajaran, membuat keputusan dan sumber sekolah dalam kalangan guru-guru sekolah menengah Daerah Machang Kelantan, Analisis Regresi Berganda (Multiple Regression) dijalankan. Dapatan analisis ini dipaparkan dalam jadual di bawah. Jadual 13 menunjukkan ringkasan keputusan ujian tersebut. Nilai $\mathrm{R}^{2}$ iaitu .361 menunjukkan hanya $36.1 \%$ dari kesemua pembolehubah tidak bersandar mempengaruhi komitmen guru. Ini bermaksud, terdapat sekurang-kurangnya satu pembolehubah tidak 
bersandar yang signifikan sebagai pengaruh terhadap komitmen guru dalam kalangan guru-guru sekolah menengah Daerah Machang. Dapatan ini menggambarkan hubungan yang sederhana di antara kelima-lima pembolehubah terhadap komitmen guru berdasarkan nilai pemalar korelasi $\left(\mathrm{R}=.612^{\mathrm{a}}\right)$.

Jadual 13

Ringkasan Keputusan Regresi Berganda

\begin{tabular}{lllll}
\hline Model & $\mathrm{R}$ & $\mathrm{R}$ kuasa dua & $\mathrm{R}^{2}$ diubahsuai & Ralat Piawai \\
\hline 1 & $.612^{\mathrm{a}}$ & .374 & .361 & .41627 \\
\hline
\end{tabular}

Jadual 14 pula menunjukkan keputusan analisis varians satu hala (ANOVA) yang menunjukkan terdapatnya signifikan antara pembolehubah-pembolehubah bersandar iaitu komitmen dengan 5 pembolehubah tidak bersandarHasil analisis ANOVA menunjukkan nilai $p$ signifikan secara statistik $\mathrm{F}(5)=28.959, p=.000^{\mathrm{b}}$ ).

Jadual 14

Keputusan Ujian ANOVA Regresi Berganda

\begin{tabular}{lllll}
\hline Sum of squares & df & Mean Square & F & P \\
\hline 25.090 & 5 & 5.018 & 28.959 & $.000^{\mathrm{b}}$ \\
41.934 & 242 & .173 & & \\
67.024 & 247 & & & \\
\hline
\end{tabular}

Jadual 15

Pengaruh Terhadap Komitmen Guru-guru Sekolah Menengah Daerah Machang

\begin{tabular}{lllll}
\hline Pembolehubah & $\mathrm{B}$ & $\operatorname{Beta}(\beta)$ & Nilai t & Signifikan \\
\hline Konstan & 2.519 & & 11.092 & .000 \\
Hubungan dengan murid & -.045 & -.110 & -1.786 & .075 \\
Bekerjasama & .151 & .242 & 3.873 & .000 \\
Sumber-sumber Sekolah & .001 & .002 & .031 & .975 \\
Membuat Keputusan & .184 & .331 & 5.036 & .000 \\
Inovasi Pengajaran & .232 & .300 & 4.295 & .000 \\
$\mathrm{R}$ & $.612^{\mathrm{a}}$ & & & \\
$\mathrm{R}^{2}$ & .374 & & & \\
$\mathrm{R}^{2}$ diubahsuai & .361 & & & \\
Ralat Piawai & .416 & & & \\
\hline
\end{tabular}

Berdasarkan Jadual 15 pula, daripada kelima-lima dimensi pembolehubah tidak bersandar tersebut, 3 daripadanya telah menunjukkan pengaruh yang tinggi terhadap komitmen guru iaitu dimensi bekerjasama, dimensi membuat keputusan dan dimensi inovasi pengajaran dengan nilai $p$ dan beta masing-masing adalah $(\beta=.242, t=3.873),(\beta=.331, t=5.036)$ dan $(\beta=.300, t=4.295)$. Walau bagaimanapun, pembolehubah membuat keputusan menunjukkan pengaruh tertinggi terhadap komitmen guru-guru tersebut. Dapatan ini membuktikan persamaan konsep iklim sekolah yang dibina oleh Fisher \& Fraser (1990) dengan dapatan kajian. Tiga dimensi iaitu bekerjasama, membuat keputusan dan inovasi pengajaran dilihat mempengaruhi komitmen guru. Manakala dimensi iklim sekolah iaitu hubungan dengan murid tidak mempengaruhi 
komitmen guru $(\beta=-.110)$ dan juga sumber-sumber sekolah yang hanya menunjukkan pengaruh yang terlampau rendah iaitu $(\beta=.002)$.

\section{PERBINCANGAN DAN KESIMPULAN}

Dapatan kertas kerja ini telah memberi sumbangan yang lebih terhadap penambahbaikan di sekolah khasnya dalam memantapkan tahap komitmen guru sekiranya ianya dinilai dari aspek iklim sekolah. Ia menunjukkan bahawa sesungguhnya, aspek iklim sekolah adalah satu aspek yang perlu dititik beratkan di semua organisasi pendidikan kerana sumbangannya yang positif kepada tahap komitmen guru. Dapatan ini juga dapat memberi sumbangan dan panduan kepada pihak sekolah supaya menitikberatkan elemen proses membuat keputusan untuk mendapatkan komitmen guru di sekolah.

Secara khususnya kajian ini menyokong andaian Steers (1977) yang telah mengemukakan satu model peramal dan hasil komitmen pekerja terhadap organisasi apabila pekerja terus berkhidmat dalam organisasi yang sama. Terdapat beberapa faktor peribadi yang berhubung dengan komitmen pekerja terhadap organisasi seperti faktor umur dan jantina, Kajian mendapati bahawa guru perempuan lebih komited bekerja berbanding guru lelaki, serta guru yang lebih berpengalaman mengajar mempunyai tahap komitmen yang lebih tinggi berbanding guru yang lebih muda. Selain daripada itu, konsep iklim sekolah yang diperkenalkan oleh Fisher \& Fraser (1990) di mana mengelaskan iklim sekolah kepada lima dimensi juga boleh diterima pakai seperti bekerjasama, hubungan dengan murid, sumber-sumber sekolah, membuat keputusandan inovasi pengajaran juga boleh dibuat sebagai rujukan. Walau bagaimanapun, dua dimensi yang tersenarai di atas seperti hubungan dengan murid dan sumber-sekolah tidak begitu memberi signifikan terhadap komitmen guru, tetapi dimensi membuat keputusan dan bekerjasama sangat mempengaruhi komitmen guru secara dasarnya. Dapatan kajian ini juga bersamaan dengankajian-kajian lepas dan ini mengukuhkan lagi dapatan terdahulu seperti Abdul ManafMusa (1998), Taylor dan John (2002), Taylor \& John 2002; Smith 2009), Smith 2009; Sezgin (2009), NajeemahMohd Yusoff (2012), Collie, Shapka dan Perry (2011), Arumugam R., Chee C. L. (2015). Dapatan kajian ini juga dilihat sama dapatannya dengan dapatan oleh Shapka dan Perry (2011) terhadap dimensi iklim sekolah sebagai dimensi peramal kepada komitmen guru kerana hanya tiga dimensi iklim sekolah yang signifikan terhadap komitmen guru.

Dapatan ini mungkin menimbulkan persoalan iaitu adakah hasrat kerajaan dalam melahirkan guru sebagai pengasuh, pendidik yang mudarris, mualim, muaddib, murabbi dan mursyid akan terlaksana sekiranya pemimpin sekolah masih tidak mampu untuk mempengaruhi komitmen guru. Maka dapatan ini memberi implikasi terhadap keperluan pihak atasan seperti Kementerian Pendidikan Malaysia dan pihak sekolah

dalam meningkatkan tahap komitmen guru. Pihak Kementerian Pendidikan Malaysia sebagai contoh perlu melibatkan guru-guru seperti mendapatkan pandangan dan idea sebelum sesuatu keputusan dibuat. Kajian terdahulu menunjukkan bahawa penglibatan secara kolaboratif menyebabkan pekerja menjadi lebih komited untuk mencapai matlamat yang telah ditetapkan bersama-sama pihak pentadbiran (Smylie \& Denny, 1990). Menurut Datuk Seri Mahdzir Khalid dalam Harian Metro, 1 Ogos 2016, hasrat murni tidak akan menjadi kenyataan sekiranya pengurus pendidikan tidak menghayati aspirasi PPPM dan mengubah cara bekerja daripada berorientasikan proses kepada berteraskan keberhasilan dan perubahan ini perlu kepada penglibatan secara kolaboratif.

\section{RUJUKAN}

Abdul Manaf Musa. (1998).Faktor- faktor Yang Mempengaruhi Komitmen Guru Sekolah Rendah Terhadap Organisasi. Fakulti Sains Kognitif dan Pembangunan Manusia. Universiti Malaysia Sarawak.

Alimuddin Mohd Dom. (2008). Persidangan Kebangsaan Pelan Induk

Pembangunan Pendidikan,Ucaptama Seminar PIPP.Kementerian Malaysia: Institut Perguruan Temenggung Ibrahim.

Chua, Y. P. (2006). Kaedah Penyelidikan. Edisi Pertama. Malaysia: McGraw-Hill (Malaysia). 
Clark, R. .E. (1994). “Media will never influence learning”, Educational Technology Research and Development, 42, 21-29.

Collie, R .J., Shapka, J.D.,\& Perry, N. E. (2011). Predicting teacher commitment: The impact of school climate and social-emotional learning. Journal of Psychology in the Schools. 48 (10):1034-1048.

Crosswell, L. J. (2006).Understanding teacher commitment in times of change

Faculty of Education Queensland University of Technology.

Fisher, D.L. \& Fraser, B. J. (1990).School Climate : Assessing and improving school environment (Set: Research Information for Teachers No.2, Item 4) Melbourne Australia. Australian Council For Educational Research.

Ghaith, G. (2003). The Relationship between forms of instruction, achievement and perception of classroom climate. Educational Research. 45, 83-93.

Goktruk, S., \& Muller, R. O. (2010). Multidimensionaly of teacher participation in school decision making. Journal of Applied Sciences, 10 (14), 1421-1427.

Hair, J. F., Money, A. H., Samouel, P.,\& Page, M. (2007). Research methods for business. John Wiley \& Sons, Ltd. West Sussex, England.

Harpin, A.W.\& Croft, D.B.(1963). The Organizational Climate of School. Chicago, Midwest Administration Centre University of Chicago.

Huberman, M. (1993). The Lives of Teachers (J. Neufeld, Trans.). London: Cassell VilliersHouse.

Ibrahim Mamat .(1993). Kepimpinan Sekolah: Teori UntukPraktis. Kuala Lumpur. Kumpulan budiman Sdn . Bhd.

Johnson, B., Steven, J.J. \& Zvoch, K. (2007).Teacher's perception of School Climate : A Validity Study of Scores From the Revised School Level Environment Questionnaire. Educational and Psychological Measurement. 67. 833-850.

Kementerian Pelajaran Malaysia. (2007). Pelan Induk Pembangunan Pendidikan (PIPP)2006-2010.

Kementerian Pelajaran Malaysia. (2012). Laporan awal ringkasan eksekutif Pelan Pembangunan Pendidikan Malaysia 2013-2025. Putrajaya: Kementerian Pelajaran Malaysia.

Kerr, D., Ireland, E., Lopes, J., Craigh, R., \& Clever, E. (2004). Citizenship education longitudinal study: second annual report:First longitudinal study. National Foundation for Educational Research.

Mahdzir Khalid. (2016, 1 Ogos). Sasar Pendidikan Terbaik Dunia. Harian Metro.

Maisura Mohd Yunus. (2007). Iklim Organisasi dan Hubungannya dengan Gelagat Kewarganegaraan Organisasi di Kalangan Guru-Guru Sekolah Menengah Daerah Pontian Johor. Skudai, Johor: Universiti Teknologi Malaysia.

Mohd Ramzan Awang. (2014). Pengaruh amalan kepimpinan penolong kanan pentadbiran dan iklim sekolah sihat ke atas komitmen guru di sekolah menengah kebangsaan cluster cemerlang. Doktor Falsafah Universiti Utara Malaysia.

Najeemah Mohd Yusof. (2012).School climate and Teachers commitment:A Case Study in Penang Malaysia. University Sains Malaysia.

Nias, J. (1981). "Commitment" and motivation in primary school teachers. Educational Review, 33(3), 181-190.

Ong Chong Sooi.(1995). "Komitmen dan prestasi organisasi: Cabarankepada pengurus pendidikan", Masalah Pendidikan, 19.

Sahban Muksan. (1989). Hubungan guru dengan pengetua dalam proses pembuatan keputusan. Tesis Sarjana Yang Tidak Diterbitkan.Kuala Lumpur: Universiti Malaya.

Sainul Hermawan. (2002).Komitmen dan Pengaruhnya Terhadap Kinerja Aparatur Pada Secretariat Daerah Kabupaten Kendari (Thesis) Program Pasca Sarjana Magister Manajemen Universitas Gajah Mada.

Saodah Abd. Rahman. (2016, 5 Ogos). Guru Sebagai Pengasuh, Pendidik. Utusan Malaysia.

Sapora Sipon. (2007, 27 Julai). Pendidik Mesti Bijak Kawal Emosi. Utusan Malaysia.

Sauro, J. (2010).Should you use 5 or 7 point scales?.Dipetik dari http://www.measuringu.com/blog/scalepoints.php dimuat turun pada 25 Julai 2016.

Smith, L. D. (2009). School climate and teacher commitment. (Doctoral Dissertation). University of Alabama.

Smylie, M. A., \& Denny, J. W. (1990). Teacher leadership: Tensions and ambiguities inorganizational perspective. Educational Administration Quarterly, 26(3), 235-259. 
Thien, Nordin, T. Ramayah. (2014). Validating teacher Commitment Scale Using a Malaysian Sample. AprilJune . 1-9 SAGE.

Zabidi Abdul Razak. (2006). Ciri iklim berkesan: implikasinya terhadap motivasi pembelajaran. Jurnal Pendidikan (Keluaran Khas ). Fakulti Pendidikan. UKM, Bangi.21. 3-19.

Zabidi Abdul Razak. Kepimpinan berasaskan permuafakatan ke arah peningkatan budaya mengkaji di kalangan guru. Prosiding Seminar Penyelidikan Pendidikan. 15-16 September 2005. Sarawak: Institut Perguruan Batu Lintang. 